\title{
Using Digital Techniques with Interviews
}

\author{
Natalie Kononenko \\ University of Alberta \\ Edmonton, Alberta. Canada
}

Digital technologies permit many advances in folklore research. Here we describe how sound files can be indexed and the index then used to find material in the actual sound recording. This technique requires programming that takes the user to the appropriate point in a sound file. The programming was developed at the University of Alberta through the support of TAPoR, the Text Analysis Portal for Research. A similar commercial program is available through Greenstone. Although this technique was applied to Ukrainian recordings, it can be used with recordings in any language.

The use of digital technology is but the latest step in a long line of advances in the collecting and processing of folklore data. Folklore scholarship began as the collection and study of texts. At first, collectors were not scholars, but amateur lovers of folklore. They would hear a story and, becoming enchanted with it, seek to reconstruct it at home and on paper. They essentially retold in written form what they had heard in an oral setting. With time, the artistry of the folk performer came to be recognized more and more. Folklore became a scholarly pursuit and collectors tried to record the oral performance as accurately as possible. This was very difficult when the performer was speaking or singing and the collector had to try and write down the folk text by hand. Various techniques were used to increase fidelity to the oral text.

Sound recording, first on wax cylinders, then on tape, then cassettes, and now digitally has been the standard way of recording a folk performance for a long time. Video recordings, both tape and digital, are now also widely done. Most texts are collected as sound files. Yet, sound recordings present many challenges. How does one work with the large volume of material that it is now possible to record? One obvious answer is to take a recording and to transcribe it, thus producing a text on paper which can be read, annotated, and so forth. But transcription is extremely time-consuming and laborious. Estimates range from three to four hours of transcription to one hour of sound recording, up to seven hours for one hour. If one has 150 hours of interviews, transcription is virtually out of the question.

The second solution is to note where a particular topic is discussed, 
either at the time of collection or on listening to the tapes back home. One can then go to the appropriate tape and fast forward, rewind, and otherwise search until the appropriate point in the text or interview is found. Digitization makes this process easier in the sense that fastforwarding and rewinding are not necessary. The tape is a physical object and must be moved through the recorder heads. The digital recording is a virtual object and going to the desired point in a recording, once that point is known, requires merely dragging the cursor to the correct position. Sound files that are on cassette tapes can easily be digitized as WAV or mp3 files. For most purposes, mp3 files, which are much smaller in size, provide sufficient sound fidelity.

While going to a particular position is easy in a digitized sound file, how can one know what the correct position is and how can one be sure if the field notes directing the researcher to the appropriate tape are accurate? If there is a transcription of the sound file and if that transcription is in digital form, a simple word search yields the desired results. But, as already noted, transcription is extremely labor intensive. The current technique is indexing. Indexing requires a template. Once the template is in place, and templates can be modified as one works, indexing is relatively quick. One does not need to go back and forth and listen several times as with transcription. Indexing can generally be done on a single, almost real time, pass through the material, especially once the indexer is familiar with the template. For each sound file, indexing produces a list of the template categories that are present on that recording plus the times in the recording when the topics are discussed.

The list of categories in the index becomes a set of keywords. The keywords can be searched or the user can scroll down the keyword set. When the user finds the material of interest, he clicks on the keyword. This takes him to a list of the files in which the topic appears. The next step is to select the file, click, and play. The Ukrainian Audio database, which is available on the internet at:

http://projects.tapor.ualberta.ca/UkraineAudio takes the user to the recording. Being able to go directly to a sound file instead of relying on a transcription has many virtues in addition to saving time. When one can hear the actual recording, one can get nuances of intonation, volume, and speed which are difficult to reproduce on paper. This permits better understanding of the material.

What follows is a brief description of the whole process. Researchers who would like to use this technology can obtain all of the computer programs cited and have their questions answered by 
contacting me (nataliek@ualberta.ca).

Let us take a specific interview recorded in Kopachiv in 1994 where several people talked about wedding customs. The original tape recording was made into an mp3. A "Master Interview Index Form" had been previously generated where the many steps involved in traditional weddings, baptisms, and funerals were listed. Under the category "wedding" there would be sub-categories or keywords such as: "invitation", "making the wedding bread", "church service", "civil ceremony", "thank you for the daughter", "post-wedding carnival" etc.

When the Kopachiv recording is processed pertinent information about the interview is entered at the top of the form: interviewer, interviewees, place, date, etc. The mp3 is then listened to and the times when a particular topic is discussed are noted down. At the end of the interview, topics which were not discussed are deleted from the form. Part of the resulting Interview Index Form is shown in Figure 1. The first three topics shown were on the original Master Form (invitation, thank you for the daughter, post-wedding carnival) but then the interviewees talked about something not normally associated with weddings "б'ють кашу" [breaking the kasha] so this item was added. With practice, the person indexing the mp3 can do this almost in real time as all that has to be noted are the start and stop times of a topic. If something unusual is discussed, like “б' ють кашу”, the mp3 can be stopped and re-started.

Once the sound recordings have been indexed the mp3 were uploaded onto a server and all the data entered into the forms was processed by two computer programs. One program merely inserted "tags" into the document. The resultant file, when processed by software on the server, reproduces the original index form so it can be viewed online (see the top part of Figure 2).

The other program generates a more complicated output. It "scans" the Interview Forms and generates the metadata which associates each "category" and "keyword" with a recording which contains them both, together with the time point in that recording when they are referred to. A section of this XML file is shown in Figure 3. It was useful to have this XML file generated by a computer program as the file encoding the 200 hours of interviews contained over 25,000 lines. In passing it should be noted that several other simple programs had to be written to check this XML file. With there being both Latin and Cyrillic letters present, it had to be checked that no Latin letters had crept into the Cyrillic sections and vice versa. Although the letters: a, c, e, o, p etc. look the same in both languages the computer recognizes that they are ASCII in Latin and 
unicode in Cyrillic.

None of this is seen by the person searching the database. When the site is entered, a list of major categories is seen: весілля, вечорниці/ досвітки, дитина, домовик, домовини еtc. (again, some of these were not expected and were added when the mp3 were indexed). If "весілля" is "clicked" the keywords are seen: весілля - б'ють кашу, весілля батьків вішають, весілля - батько кличе на весілля, весілля - биття молодих etc. In our present example, if “весілля - б'ють кашу” is "clicked" the viewer sees just one recording: kopachiv984.mp3. When this item is "clicked" the screen shown in Figure 2 is seen. When the time point shown in the lower right of the figure: "00:07:11" is "clicked" the mp3 starts to play from that time point.

There are two major advantages to using the whole mp3, rather than cutting out the relevant section: "00:07:11 - 00:12:11". First it requires no judgment call by the person indexing the recording. Second, the person using the database may wish to hear what was said just before or even under some other keyword. This can readily be done by moving the "scroll bar" shown to the left of the "00:07:11" until the appropriate time is shown on the right end of the scroll bar.

We consider that this method of processing interviews is far superior to transcription, and requires less time to implement.

Tape/disc \#/name: kopachiv984

Interviewer: Prof. Natalie Kononenko, Nataliia Kostiantynivna Hnatiuk

Project Title: Rites of Passage/Central Ukraine

Date: November 15, 1998

Medium: CD (digitized copy, originally recorded on cassette)

Overall interview time: $\mathbf{4 7 . 1 5}$

Place/village name: selo Kopachiv, Obukhivs'kyi raion, Kyivs'ka oblast'

Interviewee (last name, first name): a folk singing (samodiial' nyi) group

Lidiia Mykolaiivna Vdovenko, DOB 1950

Halyna Afanasivna Chubata, DOB 1950

Halyna Makarivna Pylypchynko, DOB 1948

Tetiana Davydivna Skyrnyk, DOB 1951

Mykhailo Mykhailovych Solonyi, DOB 1938

$\begin{array}{cl}\text { TIME (min:sec) } & \text { SUВJECT } \\ 00.30-02.00 & \text { Весілля - запрошення } \\ 23.54-24.15 ; 25.01-32.00 & \text { Весілля - Чоботи - дякують за дочку } \\ 02.10-07.11 & \text { Весілля - циганщина } \\ 07.11-12.11 & \text { Весілля - б'ють кашу }\end{array}$

Figure 1 (part of the original Interview Index Form) 


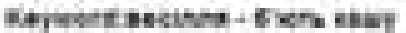

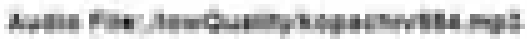

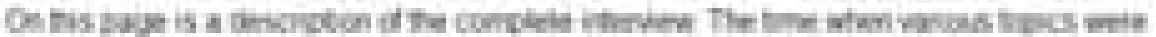

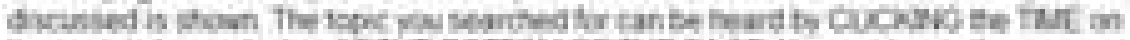

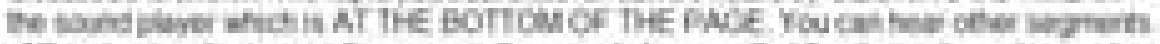

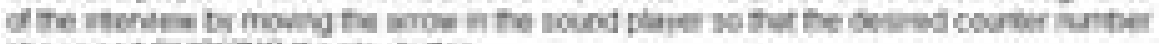

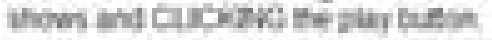
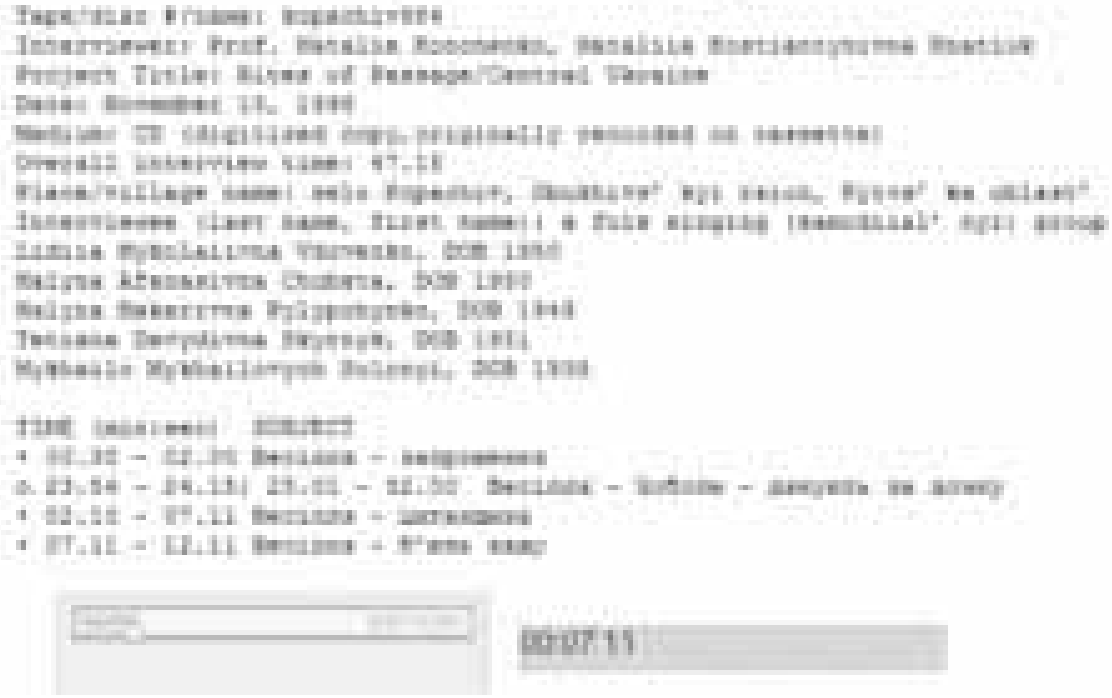

Figure 2 (the screen from the web site)

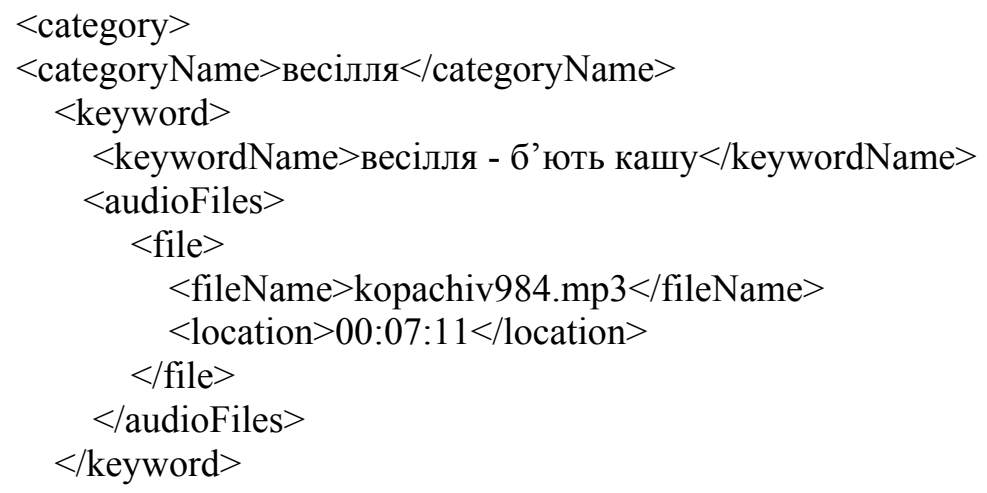

Figure 3 (part of the XML file) 